\title{
Analisis Kesesuaian UU No. 33 Tahun 2014 \\ Tentang Jaminan Produk Halal Pada Pangan Impor \\ di Indomaret Wilayah Kabupaten Kuningan
}

\author{
Mulfi Aulia ${ }^{1}$, Alya Hanifah ${ }^{2}$
}

\section{Abstrak}

Penelitian ini menggunakan metode penelitian lapangan (field research) dengan pendekatan kualitatif. Data kualitatif tentang proses pengadaan produk pangan impor dan kesesuaian produknya dengan UU JPH diperoleh melalui wawancara kepala toko, observasi dan dokumentasi gerai Indomaret wilayah Kabupaten Kuningan. Hasil penelitian ini menunjukkan, pertama, ketentuan produk pangan impor yang dapat beredar di Indonesia menurut UU JPH yaitu mencantumkan label halal yang sesuai pada produknya dan memiliki sertifikat halal dan memiliki nomor registrasi (hal ini khusus untuk produk impor bersertifikat halal luar negeri wajib melakukan registrasi ke BPJPH dan mencantumkan nomor registrasinya pada produk). Kedua, produk yang dipasok ke Indomaret wilayah Kabupaten Kuningan berasal dari satu Distribution Center (DC) yaitu DC Cirebon sehingga dapat dipastikan semua produk yang dijual di gerai Indomaret wilayah tersebut, termasuk produk pangan impor, ialah sama. Ketiga, selama masa transisi lima tahun (Oktober 2014-Oktober 2019) ternyata kurang dimanfaatkan secara maksimal oleh beberapa importir untuk melaksanakan sertifikasi halal terhadap produknya. Buktinya pada tahun 2021 ini, yang artinya telah lewat dua tahun dari masa transisi, masih ditemukan produk yang tidak berlabel halal maupun berketerangan tidak halal di Indomaret wilayah Kabupaten Kuningan.

Kata Kunci: Jaminan Produk Halal; Pangan Impor; Indomaret

\section{Abstract}

This study uses a field research method with a qualitative approach. Qualitative data on the procurement process for imported products and product sales under the JPH Law were obtained through interviews with store heads, observations and documentation of Indomaret outlets in the Kuningan Regency area. The results of this study indicate, first, the provisions for imported food products that can be found in Indonesia according to the JPH Law, namely the discovery of the appropriate halal label on the product and has a halal certificate and has a registration number (this is specifically for halal certified products

\footnotetext{
${ }^{1}$ Institut Ilmu Al-Qur'an, Jakarta

${ }^{2}$ Institut Ilmu Al-Qur'an, Jakarta
}

Analisis Kesesuaian UU No. 33 Tahun 2014 Tentang Jaminan Produk Halal Pada Pangan Impor di Indomaret Wilayah Kabupaten Kuningan 
abroad, it is mandatory to register to) BPJPH and its registration number on the product). Second, the products supplied to Indomaret in the Kuningan Regency area come from one Distribution Center (DC), namely DC Cirebon, so it can be ascertained that all products sold at Indomaret outlets in the area, including imported food products, are the same. Third, during the five-year transition period (October 2014-October 2019) it turned out that some importers had not utilized optimally to implement halal certification of products. The proof is that in 2021, which means that two years have passed since the transition period, there are still products that are not labeled as halal or labeled as not halal in Indomaret, the Kuningan Regency area.

Keywords: Halal Product Guarantee; Imported Food; Indomaret

\section{PENDAHULUAN}

Indonesia merupakan negara yang terkenal dengan keberagamannya. Keragaman tersebut disatukan dengan semboyan "Bhineka Tunggal Ika" yang berarti "berbeda- beda tapi tetap satu jua". Keberagaman Indonesia itu dimulai dari keberagaman suku, budaya hingga agama. Ada enam kepercayaan agama yang diakui Indonesia yaitu: Islam, Hindu, Budha, Kristen, Protestan dan Khonghucu. Diantara keenam agama tersebut Islam merupakan agama dengan pengikut terbesar di Indonesia bahkan di dunia dengan jumlah penduduk muslim sebanyak 229 juta jiwa atau $87,2 \%$ dari 273,5 juta jiwa penduduk Indonesia (Worldometer, 2021).

Dalam ajaran Islam, seorang muslim tidak diperkenankan memakan sesuatu kecuali yang halal. Bukan hanya halal, tetapi juga thayyib (baik). Para ulama menafsirkan thayyib sebagai pangan bergizi dan sesuai standar ilmu kesehatan (Ady, 2020:475). Allah berfirman:

"Hai manusia, makanlah yang halal lagi baik dari apa yang terdapat di bumi dan janganlah kamu mengikuti langkah-langkah setan, karena sesungguhnya setan adalah musuh yang nyata bagimu." (Q.S AlBaqarah [2]:168).

Dari ayat tersebut Allah memerintahkan manusia untuk bersyukur dan melarang manusia untuk tidak terpengaruh dengan rayuan setan termasuk rayuan melalui pangan. Dalam buku karangan Said Agil Husen Al-Munawar selaku menteri agama tahun 2001-2004 pun diperjelas bahwa perintah di atas ditujukan kepada manusia (muslim) tanpa terkecuali. Manusia harus makan dari rezeki yang telah diberikan Allah dalam keadaan halal dan thayyib (baik) (Al-Munawwar,

128 Analisis Kesesuaian UU No. 33 Tahun 2014 Tentang Jaminan Produk Halal Pada Pangan Impor di Indomaret Wilayah Kabupaten Kuningan

Mulfi Aulia \& Alya Hanifah 
2003:264). Karena itu, setiap langkah usaha manusia mulai dari mencari, menentukan pilihan, mengolah, menyajikan, dan menyimpan pangan harus benar-benar berpegang teguh kepada ketentuan Allah.

Isu kehalalan suatu produk akan selalu melekat pada konsumen muslim termasuk di Indonesia. Sebagaimana fatwa MUI tentang penetapan produk halal yang dikeluarkan pada 30 Desember 2009 yakni "makanan, minuman, obat-obatan dan lain-lain yang akan dikonsumsi atau dipergunakan oleh umat Islam wajib diperhatikan dan diyakini kehalalan dan kesuciannya". Bagi konsumen muslim, pangan halal berarti telah melalui proses sertifikasi halal oleh lembaga terpercaya seperti BPJPH yang hasilnya ditandai dengan pencantuman lambang halal pada setiap kemasan. Selain itu, lambang halal pun menandakan produk tersebut telah memenuhi persyaratan yang ditetapkan oleh hukum syariah (halalan thoyyiban) sehingga dapat dikategorikan pangan tersebut sudah layak konsumsi bagi muslim.

Adanya labelisasi halal sebagai bentuk perlindungan konsumen muslim bukan hanya diperuntukan untuk pangan yang berasal dari dalam negeri saja namun berlaku juga untuk pangan yang berasal dari luar negeri (pangan impor). Terlebih semenjak diberlakukannya kesepakatan MEA terkait kebebasan berdagang di wilayah ASEAN dalam bidang barang, jasa, investasi, tenaga kerja dan modal sehingga menyebabkan mudah masuknya pangan impor ke dalam negeri baik yang halal maupun non halal. Maka, untuk membedakan halal atau tidaknya pangan impor tersebut dapat mengacu pada Undang-Undang Nomor 33 Tahun 2014 Tentang Jaminan Produk Halal Pasal 1 ayat (11) menyatakan bahwa label halal adalah tanda kehalalan suatu produk, jika pada kemasan tidak tercantum label halal bisa diindikasikan produk tersebut mengandung unsur bahan yang diharamkan syariah karena selanjutnya pada pasal 4 ditegaskan bahwa semua produk yang masuk, beredar, dan diperdagangkan di wilayah Indonesia wajib bersertifikat halal. Lalu pada pasal 26 ayat (2) dinyatakan bahwa pelaku usaha yang memproduksi produk dari bahan yang berasal dari bahan yang diharamkan wajib mencantumkan keterangan tidak halal pada produk.

Analisis Kesesuaian UU No. 33 Tahun 2014 Tentang Jaminan Produk Halal Pada Pangan Impor di Indomaret Wilayah Kabupaten Kuningan 
Selain itu, produk pangan yang menyantumkan label halal namun tidak ada nomor sertifikasi halalnya atau bahkan ada nomor sertifikasi halalnya tetapi tidak terdaftar pada LPPOM MUI, yang artinya nomor sertifikasi halalnya palsu, dapat dikenakan sanksi administratif berupa peringatan tertulis, denda administratif, atau pencabutan Sertifikat Halal, sebagaimana diatur dalam Pasal 27 ayat (1) dan Pasal 25 UU no 33 tahun 2014. Seperti kasus produsen produk pangan kecil asal Cina yang mencantumkan label halal tanpa melalui proses sertifikasi halal pada tahun 2016 lalu (Hukumonline.com, 2021). Produk pangan berlabel halal palsu tersebut adalah Sagiko Fun Fun dan Sagiko Chocolate Oat Meal yang diimpor PT Indosagiko Sukses Global. Produk lainnya, Silang Almond Pastry dan Silang Good Vita Natural Oat Cracker yang diimpor CV Dimensi Globaltama (Republika, 3 Juni 2021). Peraturan tersebut tidak hanya menerapkan sanksi administratif, tetapi juga sanksi pidana bagi pelaku usaha yang tidak dapat menjaga kehalalan produknya padahal telah memperoleh sertifikat halal. Kejadian 2016 lalu ini menjadi momok tersendiri bagi masyarakat Indonesia khususnya bagi masyarakat muslim agar lebih teliti dalam memilah produk impor yang akan dikonsumsi. Padahal penyebaran produk pangan impor sendiri kini semakin meluas. Hal tersebut ditunjukan dengan mudah ditemukannya produk pangan impor pada gerai toko yang jumlahnya paling banyak dan tersebar luas di Indonesia yakni Indomaret.

Indomaret merupakan jaringan minimarket konvensional yang menyediakan kebutuhan pokok dan kebutuhan sehari-hari dengan jumlah gerai sebanyak 17.681 pada tahun 2020 yang tersebar luas baik di kota maupun di kabupaten (Lokadata, 2021) termasuk di kabupaten Kuningan sendiri terdapat 24 gerai Indomaret (Tiendo, 2021). Bagi masyarakat muslim khususnya di Kabupaten Kuningan sertifikat dan label halal sangatlah penting karena berfungsi sebagai pedoman untuk mempertahankan hidup secara islami (Korean Instutute of Halal Industry, 2021), terutama dalam memilah pangan impor yang berasal dari negara dengan mayoritas non muslim. Alasan pemilihan tempat penulisan ini karena lokasi tersebut mudah dijangkau oleh penulis baik dalam hal waktu, biaya, dan perolehan izin. Selain itu, di Indomaret Kabupaten Kuningan juga ditemukan produk pangan impor yang tidak berlabel halal, padahal berdasarkan observasi di lapangan

130 Analisis Kesesuaian UU No. 33 Tahun 2014 Tentang Jaminan Produk Halal Pada Pangan Impor di Indomaret Wilayah Kabupaten Kuningan

Mulfi Aulia \& Alya Hanifah 
ternyata masyarakat sekitar menganggap semua produk di gerai Indomaret di wilayahnya halal sehingga tidak menganggap perlu melakukan pemilahan dengan mengecek ada tidaknya label halal saat membeli produk sekalipun produk impor. Keberadaan produk pangan impor pada gerai konvensional seperti Indomaret ini memungkinkan dapat ditemukannya produk pangan tidak berlabel halal, tidak berketerangan tidak halal, atau bahkan produk berlabel halal namun nomor sertifikasi halalnya tidak terdaftar pada LPPOM MUI (palsu).

Oleh karena itu, sebagai upaya mengantisipasi masyarakat muslim menghindari kesalahan mengkonsumsi pangan impor non halal, maka perlu dilakukan penganalisisan produk pangan impor berlabel halal dengan fokus subjek penelitian pada gerai Indomaret di wilayah Kabupaten Kuningan yang kemudian penulis beri judul: "Analisis Kesesuaian UU No. 33 Tahun 2014 Tentang Jaminan Produk Halal Pada Pangan Impor Di Indomaret Wilayah Kabupaten Kuningan ".

\section{LANDASAN TEORITIS}

\section{Regulasi Terkait Pangan Halal}

Berikut adalah daftar produk hukum dan peraturan perundangundangan yang berkaitan dengan produk halal, meliputi barang dan/atau jasa yang terkait dengan makanan, minuman, obat, kosmetik, produk kimiawi, produk biologi, dan produk rekayasa genetik serta barang gunaan yang dipakai, digunakan, atau dimanfaatkan oleh masyarakat, yang dikeluarkan oleh Pemerintah Republik Indonesia (Halalmui.org, 2021):

Tabel 1. Regulasi Halal di Indonesia

\begin{tabular}{|c|c|c|}
\hline No & Peraturan & Ringkasan Isi \\
\hline 1 & $\begin{array}{l}\text { Undang-Undang } \\
\text { (UU) No. } 33 \\
\text { Tahun } 2014 \\
\text { tentang Jaminan } \\
\text { Produk Halal }\end{array}$ & $\begin{array}{l}\text { - } \text { Kewajiban sertifikat halal } \\
\text { - } \text { Penyelenggara Jaminan Produk Halal } \\
\text { - } \text { Ketentuan bahan dan proses produk } \\
\text { halal } \\
\text { - } \text { Tata cara memperoleh sertifikat halal } \\
\text { - Pengawasan terhadap aktifitas } \\
\text { jaminan produk halal }\end{array}$ \\
\hline
\end{tabular}

Analisis Kesesuaian UU No. 33 Tahun 2014 Tentang Jaminan Produk Halal Pada Pangan Impor di Indomaret Wilayah Kabupaten Kuningan 


\begin{tabular}{|c|c|c|}
\hline No & Peraturan & Ringkasan Isi \\
\hline & & $\begin{array}{l}\text { - Peran serta masyarakat dalam } \\
\text { aktifitas jaminan produk halal } \\
\text { - Ketentuan pidana }\end{array}$ \\
\hline 2 & $\begin{array}{l}\text { Peraturan } \\
\text { Pemerintah (PP) } \\
\text { No. } 31 \text { Tahun } \\
2019 \text { tentang } \\
\text { Peraturan } \\
\text { Pelaksanaan UU } \\
\text { No. } 33 \text { Tahun } \\
\text { 2014 (UU JPH) }\end{array}$ & $\begin{array}{l}\text { - Detil penjelasan dalam pelaksanaan } \\
\text { JPH } \\
\text { - Kerja sama antar lembaga dalam } \\
\text { penyelenggaraan jaminan produk } \\
\text { halal } \\
\text { - Biaya sertifikasi halal } \\
\text { - Penahapan kewajiban jenis produk } \\
\text { yang bersertifikat halal }\end{array}$ \\
\hline 3 & $\begin{array}{l}\text { Peraturan Menteri } \\
\text { Agama No. } 26 \\
\text { Tahun } 2019 \\
\text { tentang } \\
\text { Penyelenggaraan } \\
\text { Jaminan Produk } \\
\text { Halal }\end{array}$ & $\begin{array}{l}\text { - Detil penahapan kewajiban sertifikat } \\
\text { halal (berdasarkan jenis produk) } \\
\text { - Tata cara pendirian dan akreditasi } \\
\text { LPH } \\
\text { - Detil tata cara pengajuan } \\
\text { permohonan dan pembaruan } \\
\text { sertifikat halal } \\
\text { - Label halal dan keterangan tidak } \\
\text { halal }\end{array}$ \\
\hline 4 & $\begin{array}{l}\text { Keputusan } \\
\text { Menteri Agama } \\
\text { (KMA) No. } 982 \\
\text { Tahun } 2019 \\
\text { tentang Layanan } \\
\text { Sertifikasi Halal }\end{array}$ & $\begin{array}{l}\text { - Penetapan layanan sertifikasi halal } \\
\text { dalam masa peralihan } \\
\text { - Peran BPJPH, MUI, dan LPPOM MUI } \\
\text { dalam layanan sertifikasi halal }\end{array}$ \\
\hline 5 & $\begin{array}{l}\text { Peraturan } \\
\text { Pemerintah (PP) } \\
\text { No. } 39 \text { Tahun } \\
2021 \text { tentang } \\
\text { Penyelenggaraan } \\
\text { Bidang Jaminan } \\
\text { Produk Halal }\end{array}$ & $\begin{array}{l}\text { - Detil penjelasan dalam pelaksanaan } \\
\text { JPH } \\
\text { - Kerja sama antar lembaga dalam } \\
\text { penyelenggaraan jaminan produk } \\
\text { halal } \\
\text { - Biaya sertifikasi halal } \\
\text { - Penahapan kewajiban jenis produk } \\
\text { yang bersertifikat halal }\end{array}$ \\
\hline
\end{tabular}




\begin{tabular}{c|l|ll}
\hline No & \multicolumn{1}{|c|}{ Peraturan } & \multicolumn{1}{c}{ Ringkasan Isi } \\
\hline 6 & Undang-Undang & $\bullet$ & Proses bisnis sertifikasi Halal \\
& Nomor 11 Tahun & $\bullet$ & Kerja sama BPJPH, Lembaga \\
& 2020 tentang & & Pemeriksa Halal (LPH) \\
& Cipta Kerja & - & Auditor halal \\
& & - & Penyelia halal \\
& & - & Peran masyarakat \\
& & - Sertifikat halal \\
& & - Label halal \\
& & - Sanksi administratif \\
\hline
\end{tabular}

Dari data di atas dapat diketahui bahwa bahwa banyak sekali regulasi yang mendukung ketentuan UU JPH. Selain itu UU JPH telah mengalami perubahan dengan dikeluarkannya UU Ciptaker pada 2020. Hal ini tentu menjadi perhatian bagi para akademisi ataupun praktisi jaminan produk halal khususnya untuk menambah pengetahuannya dengan mempelajari UU JPH dalam UU Ciptaker.

Berikut adalah daftar regulai yang berkaitan dengan produk halal, meliputi barang dan/atau jasa yang terkait dengan makanan, minuman, obat, kosmetik, produk kimiawi, produk biologi, dan produk rekayasa genetik serta barang gunaan yang dipakai, digunakan, atau dimanfaatkan oleh masyarakat, yang dikeluarkan oleh LPPOM MUI (Halalmui.org):

Tabel 2. Regulasi LPPOM MUI

\begin{tabular}{c|l|l}
\hline No & \multicolumn{1}{|c|}{ Nama Dokumen } & Nomor Dokumen \\
\hline \multirow{2}{*}{1} & $\begin{array}{l}\text { Ketentuan Kelompok dan Jenis Produk } \\
\text { untuk Proses Serfifikasi Halal melalui } \\
\text { LPPOM MUI }\end{array}$ & $\begin{array}{l}\text { SK08/Dir/LPPOM } \\
\text { MUI/V/21 }\end{array}$ \\
\hline 2 & Ketentuan Sistem Jaminan Halal & $\begin{array}{l}\text { SK13/Dir/LPPOM } \\
\text { MUI/II/13 }\end{array}$ \\
\hline 3 & Daftar Bahan Tidak Kritis & $\begin{array}{l}\text { SK12/Dir/LPPOM } \\
\text { MUI/IV/XII }\end{array}$ \\
\hline
\end{tabular}

Analisis Kesesuaian UU No. 33 Tahun 2014 Tentang Jaminan Produk Halal Pada Pangan Impor di Indomaret Wilayah Kabupaten Kuningan 
al-Mizan, Vol. 5, No.2, hlm. 127-146, 2021,

P.ISSN : 2085-6792, E.ISSN : 2656-7164

\begin{tabular}{c|l|l}
\hline No & \multicolumn{1}{|c}{ Nama Dokumen } & \multicolumn{1}{|c}{ Nomor Dokumen } \\
\hline 4 & $\begin{array}{l}\text { Surat Edaran Daftar Bahan Tidak } \\
\text { Kritis }\end{array}$ & $\begin{array}{l}\text { LN11/Dir/LPPOM } \\
\text { MUI/VI/20 } \\
\text { DN29/Dir/LPPOM } \\
\text { MUI/VI/20 }\end{array}$ \\
\hline \multirow{2}{*}{5} & $\begin{array}{l}\text { Pedoman Penilaian Hasil Audit } \\
\text { Implementasi SJH di Industri } \\
\text { Pengolahan }\end{array}$ & $\begin{array}{l}\text { SK24/Dir/LPPOM } \\
\text { MUI/VII/14 }\end{array}$ \\
\hline 6 & Kebijakan Persetujuan Bahan & $\begin{array}{l}\text { SK48/Dir/LPPOM } \\
\text { MUI/XII/14 }\end{array}$ \\
\hline 7 & $\begin{array}{l}\text { Ketentuan Penulisan Nama Produk } \\
\text { dan Bentuk Produk }\end{array}$ & $\begin{array}{l}\text { SK46/Dir/LPPOM } \\
\text { MUI/XII/14 }\end{array}$ \\
\hline 8 & $\begin{array}{l}\text { Kebijakan Pendaftaran Sertifikasi } \\
\text { Halal dan Penerbitan Surat }\end{array}$ & $\begin{array}{l}\text { SK47/Dir/LPPOM } \\
\text { MUI/XII/14 }\end{array}$ \\
\hline 9 & Keterangan & $\begin{array}{l}\text { SK18/Dir/LPPOM } \\
\text { MUI/X/20 }\end{array}$ \\
\hline \multirow{2}{*}{10} & Pebijakan Analisa Laboratorium & $\begin{array}{l}\text { SK07/Dir/LPPOM } \\
\text { MUI/III/20 }\end{array}$ \\
\hline
\end{tabular}

Dari data di atas dapat diketahui betapa besarnya peran/keberadaan MUI dalam hal jaminan produk halal di Indonesia. Walau saat ini MUI tidak lagi sebagai pemberi sertifikat halal, namun perannya terhadap sertifikasi halal di Indonesia masihlah besar. Dengan adanya fatwa/regulasi-regulasi yang dikeluarkan MUI di atas menjadi perhatian bagi para pelaku usaha dan LPH dalam mengimplementasikan jaminan produk halal di Indonesia.

\section{Sejarah Lahirnya UU No. 33 Tahun 2014 Tentang Jaminan Produk Halal}

Sebagai negara dengan populasi terbesar muslim di dunia yang mencapai 87 persen, Indonesia menjadi pasar halal yang besar bagi produk-produk halal. Oleh karenanya menjadi sebuah keharusan bagi Indonesia dalam menyediakan produk-produk di dalam negeri yang tersertifikasi halal. Hal ini dilakukan dalam rangka untuk

134 Analisis Kesesuaian UU No. 33 Tahun 2014 Tentang Jaminan Produk Halal Pada Pangan Impor di Indomaret Wilayah Kabupaten Kuningan

Mulfi Aulia \& Alya Hanifah 
memberikan ketenteraman dan kenyamanan bagi penduduknya, terutama penduduk muslim.

Kehadiran negara dalam memberikan kepastian hukum kepada masyarakat menjadi penting, maka dibuatlah undang-undang dan peraturan lainnya mengenai sertifikasi halal tersebut dan salah satunya ialah Undang-undang Nomor 33 tahun 2014 tentang Jaminan Produk Halal (UU JPH) (Halalmui.org, 2021).

Setelah disetujui oleh Rapat Paripurna DPR-RI pada 25 September 2014, Rancangan Undang-Undang Jaminan Produk Halal (RUU JPH) telah disahkan oleh Presiden RI ke-6, Susilo Bambang Yudhoyono, pada 17 Oktober 2014. Selanjutnya, pada hari yang sama, Menteri Hukum dan Hak Asasi Manusia (HAM) Kabinet Indonesia Bersatu (KIB) II, Amir Syamsudin, telah mengundangkan UU tersebut sebagai Undang-Undang Nomor 33 Tahun 2014. Dalam undang-undang yang terdiri atas 68 pasal itu ditegaskan, bahwa produk yang masuk, beredar, dan diperdagangkan di wilayah Indonesia wajib bersertifikat halal. Untuk itu, Pemerintah bertanggung jawab dalam menyelenggarakan Jaminan Produk Halal (JPH).

Untuk melaksanakan penyelenggaraan JPH itu, menurut undang-undang ini, dibentuk Badan Penyelenggara Jaminan Produk Halal (BPJPH) yang berkedudukan di bawah dan bertanggung jawab kepada Menteri Agama. Selain BPJPH, pada UU JPH tersebut juga mengatur tentang peran dan fungsi dari MUI dalam sertifikasi halal, juga peran Lembaga Pemeriksa Halal (LPH) yang memeriksa dan/atau menguji kehalalan suatu produk (UU No.33 Tahun 2014 tentang Jaminan Produk Halal). UU JPH ini berlaku lima tahun sejak ditetapkan (17 Oktober 2019) seperti yang disebutkan pada pasal 67 ayat (1). Selain itu, terdapat juga ketentuan-ketentuan lainnya yang berhubungan dengan sertifikasi halal di Indonesia (Halalmui.org).

Dalam PP ini dijelaskan secara rinci mengenai tugas, wewenang dan fungsi dari institusi-institusi yang terkait dalam sertifikasi halal, yaitu: BPJPH, MUI dan LPH. BPJPH sebagai regulator sertifikasi halal di Indonesia. Sedangkan MUI mempunyai peran dalam sertifikasi auditor halal, penetapan kehalalan produk dan akreditasi LPH. 
Sedangkan LPH sendiri, mempunyai tugas melakukan pemeriksaan dan/atau pengujian kehalalan produk. Menurut Undangundang No. 33 Tahun 2014 tentang Jaminan Produk Halal (UU JPH) dan Keputusan Menteri Agama (KMA) 982 Tahun 2019 tentang Layanan Sertifikasi Halal di Indonesia, LPPOM MUI berperan sebagai Lembaga Pemeriksa Halal (LPH) yang bertugas dalam melakukan pemeriksaan terhadap kehalalan suatu produk dari sisi ilmiah.

\section{Pokok Isi Undang-Undang Nomor 33 Tahun 2014}

Dalam Kitab Hukum Ekonomi Syariah (KHES) penarikan hibah diatur dalam Buku III yang mengatur tentang Zakat dan Hibah, Bab IV tentang Hibah, Bagian Ketiga mengenai Menarik Kembali Hibah, diatur mulai dari Pasal 709 sampai dengan Pasal 723. Adapun di antara aturannya sebagai berikut:

Berikut pokok-pokok pengaturan dalam Undang-Undang Nomor 33 Tahun 2014 tentang Jaminan Produk Halal antara lain adalah sebagai berikut (Soekanto,, 1982:227-228):

1. Untuk menjamin ketersediaan produk halal, ditetapkan bahan produk yang dinyatakan halal, baik bahan yang berasal dari bahan baku hewan, tumbuhan, mikroba, maupun bahan yang dihasilkan melalui proses kimiawai, proses biologi, atau proses rekayasa genetik. Di samping itu, ditentukan pula Proses Produk Halal (PPH) yang merupakan rangkaian kegiatan untuk menjamin kehalalan produk yang mencakup penyediaan bahan, pengolahan, penyimpanan, pengemasan, pendistribusian, penjualan, dan penyajian produk.

2. Undang-undang ini mengatur hak dan kewajiban pelaku usaha dengan memberikan pengecualian terhadap pelaku saha yang memproduksi produk dari bahan yang berasal dari bahan yang diharamkan dengan kewajiban mencantumkan secara tegas keterangan "tidak halal" pada kemasan produk atau pada bagian tertentu dari produk yang mudah dilihat, dibaca, tidak mudah terhapus, dan merupakan bagian yang tidak terpisahkan dari produk.

3. Dalam rangka memberikan pelayanan publik, pemerintah bertanggung jawab dalam menyelenggarakan JPH yang pelaksanaannya dilakukan oleh Badan Penyelenggara Jaminan Produk Halal (BPJPH). Dalam menjalankan wewenangnya, BPJH

136 Analisis Kesesuaian UU No. 33 Tahun 2014 Tentang Jaminan Produk Halal Pada Pangan Impor di Indomaret Wilayah Kabupaten Kuningan

Mulfi Aulia \& Alya Hanifah 
bekerja sama dengan kementerian dan/atau lembaga terkait, Majelis Ulama Indonesia (MUI) dan Lembaga Pemeriksa Halal (LPH).

4. Tata cara memperoleh sertifikat halal diawali dengan pengajuan permohonan sertifikat halal oleh pelaku usaha kepada BPJPH. Selanjutnya, BPJPH melakukan pemeriksaan kelengkapan dokumen. Pemeriksaan dan/atau pengujian kehalalan produk dilakukan oleh LPH. LPH tersebut harus memperoleh akreditasi dari BPJH yang bekerjasama dengan MUI. Penetapan kehalalan produk dilakukan oleh MUI melalui sidang fatwa halal MUI dalam bentuk keputusan penetapan halal produk yang ditandatangani oleh MUI. BPJPH menerbitkan sertifikat halal berdasarkan keputusan penetapan halal produk dari MUI tersebut.

5. Biaya sertifikasi halal dibebankan kepada pelaku usaha yang mengajukan permohonan sertifikat halal. Dalam rangka memperlancar pelaksanaan penyelenggaraan JPH, undangundang ini memberikan peran bagi pihak lain seperti pemerintah melalui anggaran pendapatan dan belanja negara, pemerintah daerah (pemda) melalui anggaran pendapatan dan belanja daerah, perusahaan, lembaga sosial, lembaga keagamaan, asosiasi, dan komunitas untuk memfasilitasi biaya sertifikasi halal bagi pelaku usaha mikro dan kecil.

6. Dalam rangka menjamin pelaksanaan penyelenggaraan JPH, $\mathrm{BPJPH}$ melakukan pengawasan terhadap LPH; masa berlaku sertifikat halal; kehalalan produk; pencantuman label halal; pencantuman keterangan tidak halal; pemisahan lokasi, tempat dan alat pengolahan, penyimpanan, pengemasan, pendistribusian, penjualan, serta penyajian antara produk halal dan tidak halal; keberadaan penyelia halal; dan/atau kegiatan lain yang berkaitan dengan JPH.

7. Untuk menjamin penegakan hukum terhadap pelanggaran undang-undang ini, ditetapkan sanksi administratif dan sanksi pidana. 
Dari pemaparan beberapa poin pokok UU Nomor 33 Tahun 2014 di atas dapat disimpulkan bahwa tujuan penyelenggaraan Jaminan Produk Halal berdasarkan undang-undaang tersebut ialah untuk memberikan kenyamanan, keamanan, keselamatan, dan kepastian ketersediaan produk halal bagi masyarakat dalam mengonsumsi dan menggunakan produk yang dijual di wilayah Indonesia serta untuk meningkatkan nilai tambah bagi pelaku usaha untuk memproduksi dan menjual produk halal.

\section{METODE PENELITIAN}

Penelitian ini menggunakan jenis penelitian lapangan (field research) dengan teknik analisis deskriptif kualitatif. Jenis penelitian lapangan (field research) yaitu penulis terjun langsung ke tempat lokasi penelitian untuk menggali data yang diperlukan secara intensif, terinci dan mendalam terhadap suatu organisasi, lembaga atau gejala tertentu (Arikunto, 1995:58). Pendekatan penelitian yang digunakan yakni pendekatan kualitatif yang menggambarkan keadaan yang sebenarnya dari fenomena objek yang akan diteliti dan dibandingkan dengan teori, sesuai dengan masalah penelitian (Sukmadinata, 2015:60). Kemudian, penelitian yang akan dihasilkan adalah data deskriptif berupa katakata tertulis atau lisan dari orang-orang dan perilaku yang diamati serta fenomena-fenomena yang ada (Sukmadinata, 2015:72).

Oleh karena itu, penggunaan pendekatan kualitatif deskriptif berjenis field research dalam penelitian ini dipilih oleh penulis berdasarkan tujuan penelitian yang ingin mendapatkan informasi terkait ketentuan produk pangan impor, proses pengadaan serta kesesuaiannya dengan pasal 1 ayat (11), pasal 4 dan pasal 27 ayat (1) Undang-Undang Jaminan Produk Halal Nomor 33 Tahun 2014 pada gerai-gerai Indomaret yang berada di wilayah Kabupaten Kuningan.

Pemilihan lokasi didasarkan wilayah tersebut mudah dijangkau oleh peneliti baik dalam hal waktu, biaya, dan perolehan izin. Selain itu, berdasarkan hasil observasi pada gerai-gerai Indomaret di wilayah Kabupaten Kuningan ditemukan produk pangan impor yang tidak berlabel halal, padahal masyarakat sekitar menganggap semua produk di gerai Indomaret tersebut halal sehingga tidak menganggap perlu melakukan pemilahan dengan mengecek label halal saat membeli produk sekalipun produk impor.

138 Analisis Kesesuaian UU No. 33 Tahun 2014 Tentang Jaminan Produk Halal Pada Pangan Impor di Indomaret Wilayah Kabupaten Kuningan

Mulfi Aulia \& Alya Hanifah 
Untuk mengumpulkan data dalam penelitian ini peneliti menggunakan beberapa teknik sebagai berikut:

\section{Observasi}

Observasi adalah metode penelitian yang berdasarkan pengamatan yang dicatat dengan sistematik pada fenomena yang diselidiki secara teliti dan seksama (Nasution \& Fachruddin, 1993:17). Dengan teknik ini penulis dapat mengamati secara langsung terhadap data yang akan digali guna mendapatkan data yang konkrit, kemudian peneliti pun mencatat perilaku dan kejadian ataupun peristiwa sebagaimana yang terjadi pada keadaan sebenarnya tanpa ada rekayasa dan imajinasi hayalan sendiri. Teknik ini digunakan untuk mengamati secara langsung ketentuan yang berlaku bagi produk pangan impor, proses pengadaan serta kesesuaiannya dengan Undang-Undang Jaminan Produk Halal (UU JPH) Nomor 33 tahun 2014 pada pasal 1 ayat (11), pasal 4 dan pasal 27 ayat (1) pada gerai Indomaret wilayah Kabupaten Kuningan.

\section{Wawancara}

Wawancara adalah percakapan dengan maksud tertentu. Percakapan ini dilakukan oleh dua pihak, yaitu pewawancara (interviewer) yang mengajukan pertanyaan dan terwawancara (interview) yang memberikan jawaban atas pertanyaan itu, di mana hanya salah satu pihak saja yang memiliki tujuan, sementara pihak lainnya seakan-akan tidak memiliki tujuan apa pun selain menjawab pertanyaan (Herdiansyah, 2013:29-30).

Dengan melalui teknik wawancara ini betujuan untuk mendapatkan serta memperoleh data dan informasi dari narasumber terkait ketenteuan pangan impor, proses pengadaan serta kesesuaiannya dengan Undang-Undang Jaminan Produk Halal (UU JPH) no. 33 tahun 2014 pada pasal 1 ayat (11), pasal 4 dan pasal 27 ayat (1) pada gerai Indomaret wilayah Kabupaten Kuningan.

3. Dokumentasi

Metode dokumentasi adalah mencari data mengenai hal-hal yang berupa catatan, transkip, buku-buku, surat kabar, majalah prasasti, notulen rapat, dan lain sebagainya (Arikunto, 2015:206). Dokumentasi ini digunakan untuk melengkapi dan mengecek data yang diperoleh

Analisis Kesesuaian UU No. 33 Tahun 2014 Tentang Jaminan Produk Halal Pada Pangan Impor di Indomaret Wilayah Kabupaten Kuningan 
dari observasi dan wawancara. Secara umum dokumentasi yaitu pengumpulan data yang dapat berupa bukti bukti tertulis dari objek penelitian untuk memperkuat data yang diperoleh khususnya yang berkaitan dengan data gerai Indomaret di wilayah Kabupaten Kuningan.

\section{HASIL DAN PEMBAHASAN}

Penelusuran berbagai produk pangan impor yang telah beredar di Indonesia dalam penelitian ini dilakukan pada gerai-gerai Indomaret. Gerai Indomaret yang dipegang oleh PT. Indomarco Prismatama merupakan salah satu jaringan mini market waralaba terbesar di Indonesia yakni memiliki lebih dari 16.000 gerai, terdiri dari $40 \%$ milik terwaralaba dan $60 \%$ milik perusahaan yang tersebar di seluruh wilayah Indonesia (Indomaret.co.id, 2021). Awal dibukanya Indomaret adalah untuk mempermudah penyediaan kebutuhan pokok sehari-hari karyawan pada tahun 1988 di Ancol, Jakarta Utara. Dengan dibukanya gerai pertama ini, perusahaan kemudian tertarik untuk lebih mendalami dan memahami berbagai kebutuhan dan perilaku konsumen dalam berbelanja. Hasil data observasi yang telah dilakukan dapat diketahui bahwa masyarakat cenderung memilih untuk berbelanja di gerai modern atas dasar kelengkapan produk, kualitas produk, harga yang bersaing dan suasana yang lebih nyaman (Indomaret.co.id, 2021). Kini, barang dagangannya sebagian besar didapat dari 33 pusat distributor Indomaret yang menyediakan lebih dari 5.000 jenis produk berbagai macam kebutuhan pokok dan kebutuhan sehari-hari dan sangat mudah ditemukan di daerah perumahan, gedung perkantoran dan fasilitas umum karena penempatan lokasi gerai didasarkan pada motto "mudah dan hemat". (Indomaret.co.id, 2021). Dengan demikian, keberadaan produk pangan terutama pangan impor di Indomaret dapat menunjukkan produk tersebut telah tersebar luas dan seharusnya produk-produk tersebut telah mendapat izin edar dari MUI jika mengacu pada peraturan UU JPH tahun 2014.

Mengingat luasnya penyebaran gerai-gerai Indomaret dan banyaknya produk yang mereka sediakan tentu saja membuat siapa saja tidak asing dengan keberadaan gerai ini termasuk bagi masyarakat di wilayah Kabupaten Kuningan. Salah satu gerainya yaitu Indomaret

140 Analisis Kesesuaian UU No. 33 Tahun 2014 Tentang Jaminan Produk Halal Pada Pangan Impor di Indomaret Wilayah Kabupaten Kuningan

Mulfi Aulia \& Alya Hanifah 
cabang Kadugede memiliki rata-rata pengunjung per hari mencapai 200 orang dengan rata-rata minimum belanja 30.000 rupiah per orang. Hal ini disampaikan langsung oleh Kepala Toko Indomaret cabang Kadugede, Ayu Tridara, dalam sebuah wawancara langsung. Kemudian, dari 5000 jenis produk yang dapat ditemukan di gerai Indomaret, yang diteliti ada sekitar 346 produk kategori pangan impor (Indomaret.co.id, 2021).

Berdasarkan observasi yang dilakukan, dapat diketahui produk pangan impor yang berada di Indomaret berasal dari berbagai negara di belahan dunia khususnya negara-negara Asia. Dari total 346 produk dapat dipastikan 99\% diantaranya telah bersertifikat halal. Nomor regristasi yang tertera pada tabel dapat diverifikasi melalui web www.halalmui.org pada menu 'Cek Produk Halal'. Web ini adalah web resmi milik LPPOM-MUI. Didalamnya tidak hanya sebagai tempat pengecekan produk halal tetapi memuat juga berbagai informasi terkait halal lifestyle dengan rajin mengeluarkan artikel-artikel terkait. Namun nomor regristasi tersebut tidak berlaku untuk selamanya alias memiliki batasan waktu (expired date). Selain itu dari tabel di atas, tersebut 343 produk pangan impor telah bersertifikat halal dan terdapat tiga produk pangan impor tidak/belum bersertifikat halal. Produk pangan impor yang tidak/belum bersertifikat itu diantaranya: (No. 182) Lee Kum Kee Minyak Wijen (Pure Sesame Oil), (No. 274) Minuman Kopi Rasa Americano (Cold Brew Americano) BTS version dan (No. 275) Minuman Kopi Rasa Vanila Latte (Hot Brew Vanilla Latte) BTS version.

Sekilas jika dilihat dari komposisi ketiga produk tersebut, bahanbahan yang digunakan ketiga produk tersebut menggunakan bahan halal hanya saja dari negara asalnya belum mendapat sertifikat halal. Hal ini terlihat dari ada/tidaknya label halal pada produk. Berdasarkan UU PJH, semua produk yang diperdagangkan di wilayah Indonesia wajib bersertifikat halal tanpa terkecuali, baik itu produk lokal maupun impor dan meskipun komposisi produk tersebut terdiri dari bahanbahan halal tetap saja belum dapat dinyatakan halal apabila tidak ada label halal sebagai bukti kehalalanya. Padahal seharusnya jika produk tersebut bisa ditemukan di Indomaret berarti sudah beredar luas di wilayah Indonesia dan seharusnya telah bersertifikat halal. 
Dengan ditemukannya produk yang belum bersertifikat halal tersebut mengindikasikan bahwa implementasi UU JPH belum sepenuhnya dipatuhi. Terlebih diperparah dengan ketidaktahuan Kepala Toko selaku pengelola barang dan masyarakat selaku konsumen akan hal tersebut. Berdasarkan hasil wawancara ketidaktahuan Kepala Toko disebabkan karena pusat yang mengatur pengadaan barang di setiap gerai Indomaret. Sementara ketidaktahuan masyarakat khususnya pelanggan Indomaret disebabkan mereka menganggap semua produk yang dijual di Indomaret tersebut pasti sudah bersertifikasi halal. Hal ini diketahui dari hasil wawancara kepada salah satu pelanggan yakni Pak Aldi (45) yang mengaku tidak pernah mengecek label halal pada setiap produk yang dibelinya karena menganggap semua produk yang dijual di Indomaret tersebut pasti sudah bersertifikat halal.

Lantas, bagaimana dengan produk yang tidak halal alias mengandung bahan yang berasal dari bahan yang diharamkan? pada Pasal 2 ayat (2) PP Nomor 39 Tahun 2021 menyatakan bahwa produk yang berasal dari bahan yang diharamkan dikecualikan dari kewajiban bersertifikat halal. Pelaku usaha pun wajib memberikan keterangan tidak halal pada produk tersebut yang dapat berupa gambar, tanda, dan/atau tulisan. Hal ini juga senada dengan isi Pasal Nomor 33 Tahun 2014. Apabila pelaku usaha yang memproduksi, mengedarkan, maupun memperdagangkan produk tidak halal tersebut tidak memenuhi kewajiban memberi keterangan tidak halal, maka ada sanksi yang diberikan. Sesuai Pasal 27 ayat (2) UU Nomor 33 Tahun 2014, pelaku usaha tersebut akan dikenai sanksi administratif berupa teguran lisan, peringatan tertulis, atau denda administratif.

\section{PENUTUP}

Berdasarkan pemaparan pada bab-bab sebelumnya, penulis mengambil kesimpulan bahwa:

1. Ada 2 ketentuan produk pangan impor untuk dapat diperjual belikan di wilayah Indonesia menurut UU Nomor 33 Tahun 2014 Tentang Jaminan Produk Halal, yaitu:

a. Halal, yaitu pelaku usaha memiliki sertifikat halal dan mencantumkan label halal yang sesuai pada produknya.

142 Analisis Kesesuaian UU No. 33 Tahun 2014 Tentang Jaminan Produk Halal Pada Pangan Impor di Indomaret Wilayah Kabupaten Kuningan

Mulfi Aulia \& Alya Hanifah 
b. Nomor registrasi, khusus untuk produk impor bersertifikat halal luar negeri wajib melakukan registrasi ke BPJPH dan mencantumkan nomor registrasinya pada produk.

2. Untuk pengadaan produk impor di gerai Indomaret wilayah Kabupaten Kuningan adalah sama, yaitu:

a. Setiap gerai Indomaret memiliki sistem informasi yang akan menginput secara otomatis barang yang terjual dan tersisa dalam gerai dan sistem ini telah terhubung langsung dengan sistem DC masing-masing. termasuk wilayah Kabupaten Kuningan yang terhubung dengan sistem DC Cirebon.

b. DC Cirebon akan melakukan pengiriman barang setiap 2 hari sekali ke gerai-gerai di wilayah 3 Cirebon (Kota dan Kabupaten Cirebon, Kabupaten Indramayu, Kabupaten Majalengka dan Kabupaten Kuningan), mengikuti data barang yang telah habis sesuai system di gerai masingmasing, jadi pengiriman barang di setiap gerai pastilah berbeda.

3. Setelah melakukan analisis terhadap gerai Indomaret di wilayah Kabupaten Kuningan dan kesesuaianya dengan UU Nomor 33 Tahun 2014 Tentang Jaminan Produk Halal pasal 1 ayat (11), pasal 4 dan pasal 27 ayat (1) dapat disimpulkan bahwa kurang terlaksananya UU JPH di wilayah tersebut. Hal ini didasari dengan ditemukannya fakta bahwa:

a. Ditemukan tiga produk pangan impor yang belum berlabel halal, produk tersebut ialah : Lee Kum Kee Minyak Wijen asal Cina, Paldo BTS Cold Brew Americano asal Korea dan Paldo BTS Hot Brew Vanilla Latte asal Korea. Sekilas jika dilihat dari komposisi ketiga produk tersebut, bahan-bahan yang digunakan ketiga produk tersebut menggunakan bahan halal hanya saja dari negara asalnya belum mendapat sertifikat halal. Hal ini terlihat dari ada/tidaknya label halal pada produk. Berdasarkan UU $\mathrm{PJH}$, semua produk yang diperdagangkan di wilayah Indonesia wajib bersertifikat halal tanpa terkecuali, baik itu produk lokal maupun impor. Hal ini 
merupakan tugas pemerintah selaku eksekutor untuk melaksanakan UU JPH.

b. Kurangnya pengetahuan akan keberadaan regulasi UU JPH baik dari pihak pengelola gerai Indomaret maupun konsumen terhadap produk pangan impor yang dijual di Indomaret wilayah Kabupaten Kuningan, yang mana hal ini adalah salah satu tugas dari BPJPH untuk melakukan sosialisasi, edukasi serta publikasi produk halal kepada masyarakat.

\section{DAFTAR PUSTAKA}

Adam, Panji. "Kedudukan Sertifikasi Halal dalam Sistem Hukum

Nasional Sebagai Upaya Perlindungan Konsumen Dalam Hukum Islam". Jurnal Amwaluna 10. 2017.

Ady, Syahputra. "Pengaruh Labelisasi Halal Terhadap Keputusan

Masyarakat Kecamatan Perbaungan Dalam Pembelian Produk Makanan Dalam Kemasan". Jurnal Ekonomi dan Keuangan 2. No.8, 2020.

Agil Husen Al Munawar, Said. Makanan dan Miniman Manusia Menurut Islam. Jakarta: Ditjen Bimas Islam, 2003.

Amin, Ma'ruf. Fatwa Produk Halal: Melindungi dan Menentramkan. Jakarta: Pustaka Jurnal Halal, 2010.Departemen Agama RI. Panduan Sertifikasi Halal. (t.tp: t.p, 2008).

Amin, Ma'ruf. "Halal Berlaku Untuk Seluruh Umat". Jurnal Halal LPPOM MUI. no. 1, 2013.

Amri, Syaiful dan M. Jamil Ardiansyah. "Analisis Yuridis Kewenangan Majelis Ulama Indonesia Dalam Penyelenggaraan Jaminan Produk Halal". Jurnal Ilmiah UIN Sumatera Utara 21. 2016.

Durrotul Faridah, Hayyun. "Sertifikasi Halal Di Indonesia: Sejarah, Perkembangan dan Implementasi". Journal of Halal Product and Research 2. no. 2. 2019.

Eri Safira et.al., Martha. “Masyarakat Milenial Melek Hukum Akselerasi Produk Halal Berjaya di Pentas Dunia". Journal of Law Family Studies Al syakhisiyyah 1. no. 2. 2019.

Faidah, Mutimmatul. "Sertifikasi Halal di Indonesia dari Civil Society Menuju Relasi Kuasa antara Negara dan Agama", Jurnal Studi Keislaman 10. 2017.

144 Analisis Kesesuaian UU No. 33 Tahun 2014 Tentang Jaminan Produk Halal Pada Pangan Impor di Indomaret Wilayah Kabupaten Kuningan 
Hartono, Nono dan Ambar Jamilah. “Analisis Perilaku Konsumen Terhadap Tingkat Kepentingan Label Halal Pada Bahan Pangan (Studi Kasus: Masyarakat Desa Bobos Kecamatan Dukupuntang Kabupaten Cirebon)". Jurnal Syirkatuna 8. 2016.

Herdiansyah, Haris. Wawancara, Observasi, Focus Group: Sebagai Instrumen Penggalian Data Kualitatif. Jakarta: Rajawali Pers, 2013.

Izzuddin, Ahmad. "Pengaruh Label Halal, Kesadaran Halal Dan Bahan Makanan Terhadap Minat Beli Makanan Kuliner", Jurnal Penelitian Ipteks 3. no. 2. 2018.

Jannah, Akyunul. Gelatin, Tinjauan Kehalalan dan Alternatif Produksinya. Yogyakarta: Sukses Offset, 2008.

Karimah, Iffah. "Perubahan Kewenangan Lembaga-Lembaga Yang Berwenang Dalam Proses Sertifikasi Halal”. Jurnal Syariah 3. 2015.

Konoras, Abdurrahman. Jaminan Produk Halal di Indonesia Perspektif Hukum Perlindungan Konsumen. Depok: Rajagrafindo Persada, 2017.

Nana, Syaodih Sukmadinata. Metode Penelitian Pendidikan. Bandung: Remaja Rosda Karya, 2015.

Nanda, Kurnia Fitra dan Retty Ikawati. "Hubungan Persepsi Label Halal MUI Terhadap Minat Beli Produk Makanan Pada Mahasiswa Fakultas Ilmu Kesehatan Universitas Muhammadiyah Surakarta". Journal of Food and Culinary 3. no. 1. (2020).

Nasution, Farid dan Fachruddin. Penelitian Praktis. Medan: Pustaka Widya Sarana, 1993.

Undang-Undang Nomor 33 Tahun 2014 Tentang Jaminan Produk Halal.

Soekanto, Soerjono. Suatu Tinjauan Sosiologi Hukum Terhadap MasalahMasalah Sosial. Bandung: Alumni, 1982.

Wawancara dengan Kepala Toko, Ahmad Hidayat. Kuningan, 18 Juli 2021.

Wawancara dengan Kepala Toko, Ayu tridara. Kuningan, 17 Juli 2021.

\section{Websites}

http://www.halalmui.org/mui14/main/page/regulasi-halal-diindonesia-halal-regulation-in-indonesia, diakses 11 Juni 2021 
https://indomaret.co.id/, diakses pada 26 Juli 2021

https://indomaret.co.id/korporat/seputar-indomaret/peduli-danerbagi/2021/07/16/sejarahdan-visi/, diakses pada 26 Juli 2021

https://indomaret.co.id/mitra/info-pemasok/syarat-pemasok.html diakses pada 2 Juni 2021

https://lokadata.id/data/jumlah-gerai-indomaret-2015-2020-1586939036 diakses pada 2 Juni 2021

https://www.halalmui.org/mui14/main/detail/sejarah-perundangundangan-pelayanan-sertifikasi-halal-di-indonesia, diakses 11 Juni 2021.

https://www.halalmui.org/mui14/main/page/faq-sertifikasi-halal ${ }_{\llcorner}$ diakses 11 Juni 2021.

https://www.halalmui.org/mui14/main/page/regulasi-lppom-mui, diakses 11 Juni 2021.

https://www.hukumonline.com/berita/baca/lt57a9d34e79c47/adakandungan-non-halal-pada-produk-bersertifikat-halal--inisanksinya/ diakses pada 3 Juni 2021.

https://www.tiendeo.co.id/toko/kuningan/indomaret diakses pada 2 Juni 2021.

Korea Institute of Halal Industri, "What is the meaning of 'Halal'?", http://koreahalal.org/archives/23, diakses pada 2 Juni 2021.

LPPOM MUI Jawa Timur, "Prosedur Sertifikasi Halal", www.halalmuijatim.org, diakses 11 Juni 2021.

LPPOM MUI, "Sertifikasi Halal MUI", http://www.halalmui.org, diakses 11 Juni 2021.

Republika Online, "Ditemukan Produk Berlabel Halal Palsu", diakses pada 3 Juni 2021.

146 Analisis Kesesuaian UU No. 33 Tahun 2014 Tentang Jaminan Produk Halal Pada Pangan Impor di Indomaret Wilayah Kabupaten Kuningan 